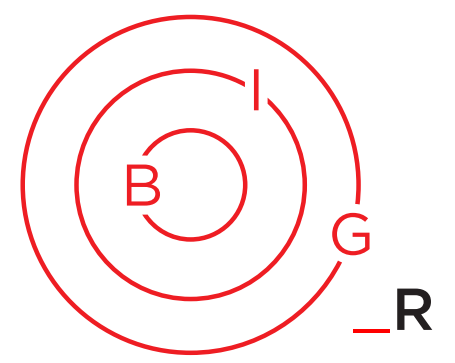

BOOK REVIEW

\title{
Border Politics in a Global Era: Comparative Perspectives
}

\author{
Emmanuel Brunet-Jailly *
}

\author{
Kathleen Staudt \\ Border Politics in a Global Era: \\ Comparative Perspectives
}

Rowman \& Littlefield Publishers, 2017

Hardback, paperback, ebook

320 pages

Border Politics in a Global Era: Comparative Perspectives by Kathleen Staudt is a book that points to what borders do to us-human beings and borderlanders. This is primarily a literature survey that is very suitable to be used as a textbook. It is wonderful: both approachable and conceptually strong to engage most educated minds, students and policy makers or any individuals that would like to learn about borders and borderlanders today. It is comparative in perspective, and also forces some thinking and reflection about what borders are, what borders do, and how they affect people who cross them. Because it is a very large survey of the literature it engages with a multitude of borders worldwide and gives the reader an excellent overview of the 'state' of global border politics at the beginning of the 21st century.

The book is made up of 13 chapters, including an introduction and a conclusion. It is organized in four parts: concepts and history, case studies (Americas, post-colonial, Europe, and maritime boundaries), public policy (security, citizenship and migration/movement, free trade), and last, the broadly conceived and metaphorically understood borderlands that are found in arts, movies and literary

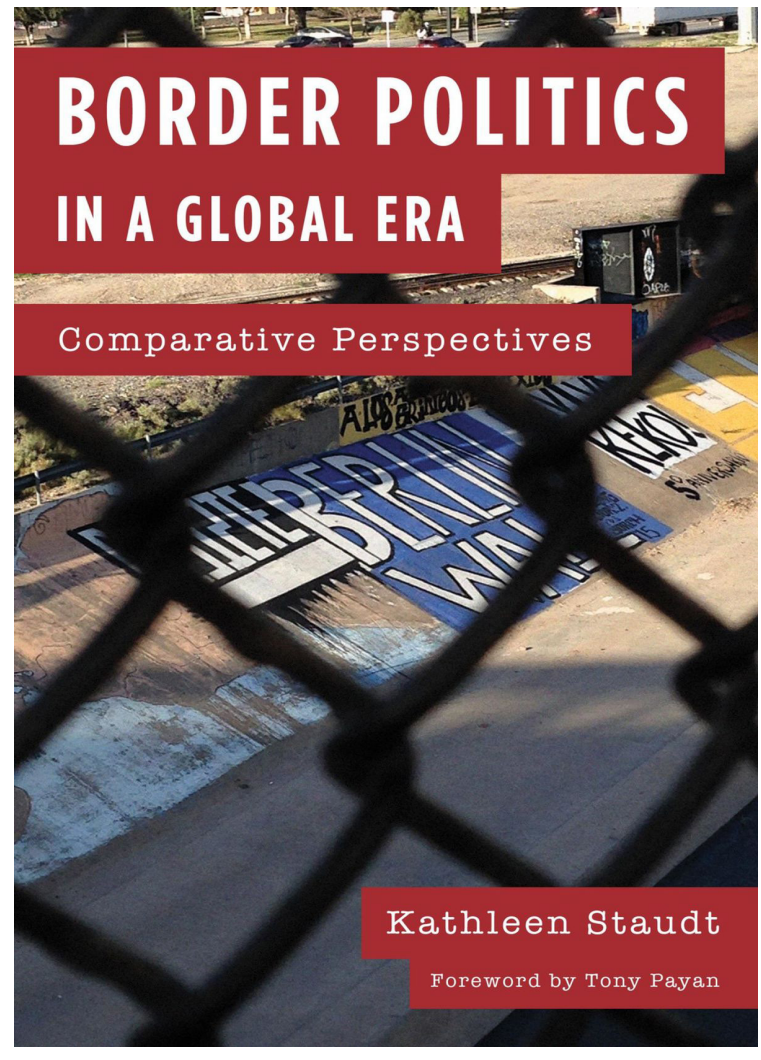

productions-these are bridging borders. In the end, the agenda of nonprofits globally and locally are also reviewed and discussed.

The normative intent is to move scholarship to study equality across interdependent contiguous states with a particular focus on wages and GDP, but without discounting for environmental damage,

* Emmanuel Brunet-Jailly, PhD, is Chief Editor of Borders in Globalization Review and Professor of Public Administration at the University of Victoria, Canada. 
Borders in Globalization Review | Volume 1 | Issue 1 | Fall 2019

Brunet-Jailly, "Border Politics in a Global Era" (book review)

and security issues. This is where Staudt suggests that investments in border-regions would contribute positively to the lessening of cross-border inequalities and would also make border policies less prone to exacerbating inequalities and in particular gendered inequalities. Indeed, there is a growing literature in border studies that confront inequality and in particular borderlands that highlight greater violence against women and children. Although Staudt does not really answer any fundamental or core questions, she makes a strong normative statement on the impact of borders on the nature of the world we live in - that is a system that organizes and rationalizes fundamental inequalities, and not only across specific contiguous countries, but worldwide.

In this regard, the third chapter offers a short and fascinating worldview. Focusing on global inequality across international boundary lines. It is a review of the border literatures discussing inequality across boundary lines from a nearly comprehensive worldwide perspective with 300 border-regions. The chapter cites the original work of Iñigo Moré (The Borders of Inequality (University of Arizona Press, 2011)), who was possibly the first scholar ever trying to present a complete set of data on border regions. However, Staudt's chapter augments and updates the work, and in doing so sets an example of what a complete data set can do and how such exemplary scholarly endeavors can contribute to the study of borders. Although it was not Staudt's stated ambition, this reviewer suspects that Chapter Three illustrates a different methodological approach to border studies. Indeed, it takes the reader away from the traditional and dominant case study approach to a systematic review of a single but all-inclusive question, data collection and answer - a magnificent methodological breakthrough.

Because Staudt's concern is inequality, the book does not ask whether there is a core idea to border studies (in that sense it is not a book about theory); however, Staudt suggests that borders are social constructions and that as social constructions, borders can change, and do not have to be violent and discriminatory. In the end, Staudt's message is that both the study of borders, and the teaching about borders can contribute to educational curriculums that lessen what she calls 'borders in minds.' As much as this reviewer agrees with her and admires her work he is left perplexed by the lack of discussion of the question of free trade across borders; but, indeed this is a book about people and borders, not about all borders but only the borders that capture people. 